\title{
PENELITIAN |RESEARCH
}

\section{Studi Toksisitas: Ekstrak Metanol Bonggol Pisang Ambon (Musa acuminata L. cv. Gros Michel) terhadap Aedes aegypti (Diptera: Culcidae)}

\author{
Toxicity Study: Methanol Extract of Ambon Banana Hump (Musa acuminata L. cv. Gros \\ Michel) against Aedes aegypti (Diptera:Culcidae)
}

Siskha Noor Komala1*, Bambang Heru Budianto ${ }^{1}$, Edi Basuki ${ }^{1}$

1 Program Studi S-2 Ilmu Biologi Fakultas Biologi Universitas Jenderal Soedirman.

\begin{abstract}
Aedes aegypti mosquito is the main vector of dengue virus causing dengue hemorrhagic fever (DHF) in Indonesia. The main preventive action is to control the presence of Ae. aegypti mosquito. Banana plants are known to contain secondary metabolite compounds acting as a natural insecticide, including the hump part. This research was conducted to evaluate to toxicity of hump of Ambon banana extract (Musa acuminata L. $c v$. Gros Michel) to dengue vector Ae. aegypti mosquito. The research used experimental method, the treatment concentration was 0.001; 0.01; 0.1; $1 ; 10 ; 100$ and 1000 ppm of Ambon banana methanol extract and 0 ppm concentration as a control, each with three replications. The variables observed were individual deaths at every stage of development and morphological damage. The data obtained were analyzed using the analysis of variety and Duncan test with 95\% confidence level. In addition, probit analysis was used to determine the value of $L C_{50}$. The results showed that the study of toxicity indicates that in the further stage of development, the toxicity of methanol extract from Ambon banana hump was less toxic. Toxicity of Ambon banana hump methanol extract was highest in egg with $L C_{50}$ value of $314,852 \mathrm{ppm}$. The methanol extract of banana Ambon has the morphological destructive activity in all development stages of Ae. aegypti.
\end{abstract}

Keywords: Aedes aegypti, hump, Ambon banana, Musa acuminata, toxicity

\begin{abstract}
Abstrak. Nyamuk Ae. aegypti merupakan vektor utama virus dengue penyebab demam berdarah dengue (DBD) di Indonesia. Upaya pencegahan utama adalah dengan mengendalikan keberadaan nyamuk $A e$. aegypti. Tanaman pisang diketahui memiliki kandungan senyawa metabolit sekunder yang memiliki aktivitas sebagai insektisida nabati, termasuk bagian bonggol. Penelitian ini dilakukan untuk mengevaluasi daya toksisitas ekstrak metanol bonggol pisang ambon (Musa acuminata L. cv. Gros Michel) terhadap nyamuk vektor dengue Ae. aegypti. Metode penelitian yang digunakan adalah metode eksperimental dengan desain penelitian rancangan acak lengkap (RAL), perlakuan yang dicoba berupa konsentrasi ekstrak metanol bonggol pisang ambon 0,$001 ; 0,01 ; 0,1 ; 1 ; 10 ; 100,1000 \mathrm{ppm}$ dan $0 \mathrm{ppm}$ sebagai kontrol, masing-masing dengan tiga kali ulangan. Variabel yang diamati adalah kematian individu pada setiap tahap perkembangan dan kerusakan morfologi. Data yang diperoleh dianalisis menggunakan analisis ragam dan uji duncan dengan taraf kepercayaan $95 \%$, dan untuk menentukan nilai $\mathrm{LC}_{50}$ menggunakan analisis probit dengan aplikasi SPSS 16. Hasil penelitian menunjukkan bahwa semakin lanjut tahap perkembangan nyamuk Ae. aegypti, ekstrak metanol bonggol pisang ambon semakin tidak toksik. Daya toksik ekstrak metanol bonggol pisang ambon paling tinggi pada telur dengan nilai $\mathrm{LC}_{50} 314,852 \mathrm{ppm}$, dengan aktivitas berupa penghambatan penetasan telur, sedangkan paling rendah pada imago dengan nilai $\mathrm{LC}_{50} 1755,077$ ppm. Ekstrak metanol bonggol pisang ambon memiliki aktivitas merusak morfologi semua tahap perkembangan Ae. aegypti.
\end{abstract}

Kata Kunci: Aedes aegypti, bonggol, pisang ambon, Musa acuminata, toksisitas

*Corresponding Author. E-mail: siskhanoorkomala25@gmail.com | Tel : +62 87728426132 


\section{PENDAHULUAN}

Penyakit demam berdarah dengue (DBD) adalah penyakit yang disebabkan oleh virus dengue dan ditularkan melalui vektor nyamuk Aedes aegypti dan Aedes albopictus. Nyamuk Ae. aegypti merupakan vektor utama virus dengue di Indonesia yang mempunyai habitat pada lingkungan dekat dengan manusia, sehingga mudah untuk menularkan virus dengue. Demam berdarah dengue merupakan penyakit endemis yang menjadi satu masalah kesehatan utama di Indonesia ${ }^{1}$. Kasus DBD di Indonesia cenderung meningkat setiap tahun, pada tahun 2015 ditemukan sekitar 126.675 kasus dari 34 provinsi dan 436 (85\%) kabupaten/kota 2 .

Upaya pencegahan utama yang perlu dilakukan untuk menurunkan kejadian DBD salah satunya adalah dengan mengendalikan keberadaan nyamuk Ae. aegypti. Pengendalian penyakit yang ditularkan nyamuk menjadi semakin sulit karena meningkatnya resistensi nyamuk terhadap insektisida ${ }^{3}$. Penggunaan insektisida sintetik dapat memprovokasi efek toksik yang tidak diinginkan terhadap lingkungan dan kesehatan manusia ${ }^{4}$. Penggunaan insektisida nabati dari tanaman, selama dekade terakhir menunjukkan berbagai kemungkinan alternatif sebagai pengganti insektisida sintetis. Tumbuhan menghasilkan berbagai senyawa metabolit sekunder, yang mudah terurai dan tidak toksik terhadap hewan yang lebih tinggi ${ }^{5}$. Senyawa metabolit sekunder pada tanaman memiliki berbagai aktivitas terhadap insekta, seperti larvasida, ovisida, pupasida, repelen dan berbagai efek biologis lainnya ${ }^{6}$. Senyawa metabolit sekunder yang memiliki aktivitas sebagai insektisida tersebut, yaitu senyawa golongan glikosida seperti tanin, flavonoid, kuinon, saponin, fenol, dan polifenol?.

Salah satu tanaman yang memiliki kandungan metabolit sekunder dan banyak digunakan dalam bidang penelitian adalah tanaman pisang. Tanaman pisang diketahui memiliki kandungan senyawa metabolit sekunder yang tinggi diantaranya saponin, triterpenoid, steroid, flavonoid, tanin dan kuinon ${ }^{8,9}$. Beberapa penelitian sebelumnya melaporkan bahwa pelepah pisang (Musa paradisiaca L.) memiliki kemampuan mortalitas $100 \%$ terhadap larva $A e$. aegypti pada konsentrasi $0,5 \mathrm{ml}$ dalam waktu 24 jam ${ }^{10}$. Selain itu ekstrak metanol akar pisang memiliki efek menghambat aktivitas oviposisi $\mathrm{Ae}$. aegypti sebesar 97,5\% pada konsentrasi $1 \%{ }^{11}$. Senyawa metabolit sekunder pada pelepah dan akar pisang tersebut terdiri dari alkaloid, flavonoid, saponin, fenol dan tanin ${ }^{11,12}$. Saat ini pengendalian nyamuk lebih difokuskan terhadap larva nyamuk.
Bagian tanaman pisang yang saat ini jarang dimanfaatkan oleh masyarakat adalah bonggol. Senyawa metabolit sekunder pada ekstrak bonggol pisang ambon memiliki aktivitas menyembuhkan luka terbuka pada tikus ${ }^{13}$. Selain itu bonggol pisang ambon juga memiliki aktivitas sebagai obat lambung terhadap tikus yang diinduksi indometachin ${ }^{14}$. Ekstrak bonggol pisang memiliki efek sebagai antibakterial dengan daya hambat dan kandungan metabolit sekunder tertinggi dibandingkan bagian tanaman pisang yang lain ${ }^{15,16}$. Pisang Ambon memiliki kandungan metabolit sekunder paling tinggi dibandingkan varietas lain ${ }^{17,18}$. Berdasarkan literatur dari penelitian terdahulu yang telah dipaparkan, senyawa metabolit sekunder pada bonggol pisang diduga memiliki aktivitas sebagai insektisida nabati. Sejauh survei literatur, kami belum menemukan informasi yang tersedia tentang bonggol pisang ambon (Musa acuminata L. cv. Gros Michel) sebagai insektisida nabati terhadap nyamuk Ae. aegypti. Oleh karena itu penelitian ini perlu dilakukan untuk mengevaluasi daya toksisitas dan aktivitas biologi dari ekstrak bonggol pisang ambon (M. acuminata L. cv. Gros Michel) terhadap Ae. aegypti. Hasil dari penelitian ini diharapkan dapat mendukung bonggol pisang ambon menjadi salah satu insektisida nabati untuk menurunkan populasi Ae. aegypti sampai populasi yang dapat ditolerir, sehingga kemampuan sebagai vektor akan berkurang bahkan menghilang.

\section{BAHAN DAN METODE}

Penelitian ini dilakukan menggunakan metode eksperimental dengan desain penelitian rancangan acak lengkap (RAL), perlakuan yang dicoba berupa konsentrasi bertingkat, yaitu 0,$001 ; 0,01 ; 0,1 ; 1 ; 10 ; 100$ dan 1000 ppm, dan kontrol $(0 \mathrm{ppm})$ masing-masing dengan tiga kali ulangan. Alat dan bahan yang digunakan berupa rotary evaporator, plat KLT, lampu UV, mikroskop disekting (stereo) dan kompon, metanol, $\mathrm{HCl}_{3}$, $\mathrm{FeCl}_{3} 2 \%, \mathrm{H}_{2} \mathrm{SO}_{4}$, etanol, reagen Liebermann, reagen Dagendrof, $\mathrm{NaNO}_{2}$, kloroform serta nyamuk Ae. aegypti strain Pangandaran hasil rearing di laboratorium insektarium Loka Litbang Kesehatan Pangandaran.

\section{A. Pengambilan Sampel Bonggol Pisang Ambon}

Sampel bonggol pisang ambon diperoleh dari perkebunan warga Desa Kadupandak Kecamatan Tambaksari Kabupaten Ciamis Jawa Barat, yang berumur dua bulan setelah panen. Berat sampel bonggol pisang ambon yang digunakan sebanyak enam kg. 


\section{B. Ekstraksi Bonggol Pisang Ambon}

Ekstraksi bonggol pisang ambon dilakukan dengan metode maserasi menggunakan pelarut metanol mengikuti metode yang dilakukan Asuquo dan Udobi' ${ }^{19}$. Sampel bonggol pisang ambon di potong tipis, kemudian dikeringkan dengan ditutupi oleh kain hitam di bawah sinar UV, lalu ditumbuk hingga menjadi simplisia dan ditimbang berat keringnya. Simplisia bonggol pisang ambon dimaserasi selama empat hari $(4 \mathrm{x}$ 24 jam), dengan perbandingan 1:8 pada hari pertama, yaitu 600gram simplisia dilarutkan pada $4800 \mathrm{~mL}$ metanol, dan 1:5 pada hari selanjutnya yaitu 600 gram simplisia dilarutkan pada 3000 $\mathrm{mL}$ metanol. Ekstraksi tersebut menggunakan metanol karena memiliki kemampuan lebih baik untuk melepaskan berbagai senyawa metabolit sekunder yang terikat pada dinding sel tanaman $^{8,11,20}$. Setiap 24 jam sekali rendaman disaring dan filtrat yang diperoleh ditampung dalam wadah penampungan (botol remaserasi). Filtrat lalu diuapkan dengan menggunakan rotary evaporator pada suhu $50^{\circ} \mathrm{C}$, sehingga diperoleh ekstrak kental dan pekat bonggol pisang ambon sebanyak 20,59 gram.

\section{Skrining Fitokimia Bonggol Pisang Ambon Menggunakan Metode Kromatografi Lapis Tipis}

Ekstrak kasar hasil maserasi diuji fitokimia menggunakan metode kromatografi lapis tipis (KLT) standar (Harborne, 1998). Fase diam menggunakan plat KLT berupa silika gel G dan fase gerak menggunakan kloroform: etanol dengan perbandingan 9:121. Ekstrak kasar dilarutkan dengan $5 \mathrm{ml}$ metanol, kemudian disimpan pada cawan dan ditutupi alumunium foil. Plat KLT dioptimasi pada suhu $110^{\circ} \mathrm{C}$, kemudian dipotong dengan ukuran $10 \mathrm{~cm} \times 2 \mathrm{~cm}$. Ekstrak diteteskan pada plat KLT menggunakan pipet kapiler berukuran 5 mikron. Plat KLT dicelupkan pada fase gerak hingga ekstrak yang diteteskan tertarik ke atas sampai tanda batas. Nilai Rf (retensi faktor) dihitung dengan rumus:

$$
\mathrm{Rf}=\frac{\text { Jarak yang ditempuh noda }}{\text { jarak yang ditempuh eluen atau pelarut }}
$$

1. Uji Flavonoid: Plat KLT disemprot dengan citroborat $\left(\mathrm{HCl}_{3}\right)$, kemudian dioptimasi pada suhu $110^{\circ} \mathrm{C}$ selama 1 menit. Hasil positif menunjukkan perubahan warna pada plat KLT menjadi kuning apabila dilihat secara langsung maupun menggunakan lampu UV dengan panjang gelombang $366 \mathrm{~nm}^{22}$.

2. Uji tannin: Plat KLT disemprot dengan $\mathrm{FeCl}_{3}$ $2 \%$, kemudian dioptimasi pada suhu $110^{\circ} \mathrm{C}$ selama 1 menit. Hasil positif menunjukkan perubahan warna pada plat KLT menjadi hijau kehitaman atau abu ${ }^{23}$.
3. Uji saponin: Plat KLT disemprot dengan reagen Liebermann, kemudian dioptimasi pada suhu $110^{\circ} \mathrm{C}$ selama 1 menit. Hasil positif menunjukkan perubahan warna pada plat KLT menjadi merah jambu ${ }^{24}$.

4. Uji alkaloid: Plat KLT disemprot dengan reagen Dragendroff dan ditambahkan $\mathrm{NaNO}_{2}$, kemudian dioptimasi pada suhu $110^{\circ} \mathrm{C}$ selama 1 menit. Hasil positif menunjukkan perubahan warna pada plat KLT menjadi kuning kemerahan atau kuning kecoklatan 25 .

5. Uji terpenoid: Plat KLT disemprot dengan $\mathrm{H}_{2} \mathrm{SO}_{4}$ (asam sulfat), kemudian dioptimasi pada suhu $110^{\circ} \mathrm{C}$ selama 1 menit. Hasil positif menunjukkan perubahan warna pada plat KLT menjadi hitam keunguan ${ }^{26}$.

\section{Rearing Nyamuk Ae. aegypti}

Tahap ini merupakan tahap persiapan, yaitu perbanyakan nyamuk Ae. aegypti secara masal di ruang insektarium Loka Litbang Kesehatan Pangandaran. Proses rearing Ae. aegypti dilakukan selama satu bulan hingga dihasilkan kohort Ae. aegypti pradewasa (larva dan pupa), dewasa, dan telur dengan jumlah yang mencukupi untuk kebutuhan uji penelitian ini.

\section{E. Uji Toksisitas Ekstrak Metanol Bonggol Pisang Ambon terhadap semua tahap perkembangan Nyamuk Ae. aegypti (Bioassay Test)}

\section{Aktivitas Ovicidal}

Uji ovicidal nyamuk Ae. aegypti dimodifikasi dari metode yang dilakukan Govindarajan ${ }^{27}$ dan Sarma, et al. ${ }^{28}$. Sebanyak 150 butir telur Ae. aegypti disimpan pada nampan berisi masingmasing konsentrasi ekstrak yang telah dilarutkan dalam $1200 \mathrm{ml}$ air keran, kemudian diamati sampai mereka menetas atau mati (tidak menetas dalam waktu lima hari), serta diamati di bawah mikroskop untuk mengamati keadaan telur setelah diberi perlakuan. Kematian telur dievaluasi 144 jam (6 hari) setelah perlakuan.

\section{Aktivitas Larvacidal}

Aktivitas larvacidal ekstrak bonggol pisang ambon dievaluasi dengan memodifikasi metode yang dilakukan oleh Krzyzaniak ${ }^{29}$. Sebanyak 20 larva instar IV dimasukkan ke dalam beker glass berisi masing-masing ekstrak yang dilarutkan dalam $200 \mathrm{ml}$ air keran. Kematian larva dihitung, kemudian nilai Lethal Concentration 50 (LC50) dihitung setelah 24 jam menggunakan analisis probit.

\section{Aktivitas Pupicidal}

Aktivitas pupicidal ekstrak bonggol pisang ambon dievaluasi dengan memodifikasi metode yang digunakan oleh Selvakumar, et al.30. 
Sebanyak 20 pupa dimasukkan ke dalam $50 \mathrm{ml}$ air keran yang mengandung konsentrasi uji pada gelas plastik kecil dan disimpan di dalam paper cup, kemudian ditutup dengan kain kasa. Kematian setiap pupa atau jumlah imago yang muncul dicatat setelah 48 jam terpapar ekstrak.

\section{Aktivitas Imagicidal}

Pengujian aktivitas imagicidal dilakukan dengan cara memasukkan ekstrak pada makanan nyamuk. Masing-masing ekstrak uji dilarutkan dalam larutan air gula $10 \%$, kemudian dimasukan ke dalam botol berukuran $100 \mathrm{ml}$. Botol yang berisi ekstrak tersebut lalu disimpan pada

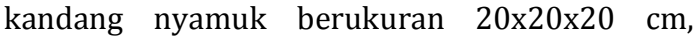
setelah itu dimasukkan 10 ekor nyamuk berumur 2 hari. Kematian setiap imago (nyamuk yang tidak mengalami pergerakan setelah pengusikan) dihitung dan dicatat setelah 48 jam terpapar ekstrak. Analisis data yang digunakan dalam penelitian ini menggunakan analisis ragam dan uji duncan dengan taraf kepercayaan 95\%, kemudian untuk menentukan nilai $\mathrm{LC}_{50}$ menggunakan analisis probit dengan aplikasi SPSS 16.

\section{HASIL}

\section{A. Kandungan Fitokimia Ekstrak Metanol Bonggol Pisang Ambon melalui Metode Kromatografi Lapis Tipis (KLT)}

Hasil analisis fitokimia pada studi ini menunjukkan bahwa ekstrak metanol bonggol pisang ambon mengandung senyawa metabolit sekunder golongan flavonoid, tannin, saponin, alkaloid dan terpenoid yang ditunjukkan dengan perubahan warna noda yang dihasilkan dan nilai Rf digunakan sebagai indikator polaritas setiap senyawa. Tabel 1 menunjukkan bahwa pada studi ini senyawa flavonoid dan tanin memiliki nilai Rf paling rendah dibandingkan saponin alkaloid dan terpenoid.

\section{B. Toksisitas $\left(\mathrm{LC}_{50}\right)$ Ekstrak Metanol Bonggol Pisang Ambon terhadap Nyamuk Ae. aegypti}

Hasil analisis uji toksisitas ekstrak metanol bonggol pisang ambon memiliki efek toksik yang berbeda, ditunjukkan dengan nilai $\mathrm{LC}_{50}$ yang berbeda terhadap semua tahap perkembangan nyamuk $A$ e. aegypti, dengan persentase mortalitas pada ekstrak di setiap tahap perkembangan berbeda signifikan dengan konsentrasi $0 \mathrm{ppm}$ atau kontrol, terutama pada konsetrasi 1000 ppm. Hasil studi menunjukkan bahwa nilai $\mathrm{LC}_{50}$ mengalami peningkatan secara bertahap seiring dengan peningkatan tahap perkembangan nyamuk Ae. aegypti (Tabel.2). Semakin lanjut tahap perkembangan nyamuk, maka semakin tinggi pula nilai LC50 yang digunakan.

\section{Analisis Morfologi Nyamuk Ae. aegypti yang dipapar Ekstrak Metanol Bonggol Pisang Ambon}

Hasil analisis morfologi nyamuk Ae. aegypti menggunakan mikroskop stereo, menunjukkan bahwa ekstrak metanol bonggol pisang ambon dapat menyebabkan kelainan pada morfologi semua tahap perkembangan nyamuk $A$ e. aegypti (Gambar.1). Senyawa metabolit sekunder pada ekstrak metanol bonggol pisang ambon menyebabkan penghambatan penetasan telur (Gambar. 1a) dan kerusakan pada saluran pencernaan larva, ditandai dengan adanya pengendapan senyawa menyebabkan usus menjadi hitam, serta adanya peningkatan lumen perut, yang kemudian menyebabkan lisis (Gambar.1b,c).

Paparan ekstrak metanol bonggol pisang ambon menyebabkan sifon tempat berlangsungnya proses respirasi pada larva mengalami pigmentasi sehingga menjadi lebih hitam dibandingkan kontrol (Gambar. 1c). Ekstrak metanol bonggol pisang ambon, dapat menyebabkan kelainan morfologi pada pupa setelah terpapar ekstrak selama 48 jam, diantaranya pupa mengalami melanisasi kutikula pada bagian sefalotorak (pupa coklat), dan kegagalan molting, sehingga proses pembentukan imago terganggu, serta terjadi penempelan eksuvia pupa pada bagian perut, kaki dan sayap (Gambar. 1d,e). Imago Ae aegypti yang terpapar ekstrak pada konsentrasi 1000 ppm, menunjukkan adanya pigmentasi pada beberapa bagian tubuh terutama pada bagian abdomen, sehingga menjadi lebih gelap dibandingkan dengan imago pada kontrol (Gambar. 1f).

Tabel. 1. Senyawa Metabolit Sekunder pada Ekstrak Metanol Bonggol Pisang Ambon Diuji melalui Metode KLT

\begin{tabular}{ccccc}
\hline No. & $\begin{array}{c}\text { Senyawa metabolit } \\
\text { sekunder }\end{array}$ & Reagen & $\begin{array}{c}\text { Warna noda yang } \\
\text { dihasilkan }\end{array}$ & Nilai Rf \\
\hline 1. & Flavonoid & HCl3 & Kuning & 0.517 \\
2. & Tannin & FeCl3 2\% & Hijau kehitaman & 0.556 \\
3. & Saponin & Hiberman & Merah jambu & 0.741 \\
4. & Alkaloid & Dagendrof & Kuning kecoklatan & 0.630 \\
5. & Terpenoid & H2SO4 & Hitam keunguan & 0.890 \\
\hline
\end{tabular}




\section{PEMBAHASAN}

Kandungan senyawa metabolit sekunder pada ekstrak metanol bonggol pisang ambon seperti yang terdapat pada Tabel 1 menunjukkan bahwa senyawa flavonoid dan tanin memiliki nilai Rf yang rendah, sifatnya lebih polar dan memiliki koefisien distribusi yang lebih besar dibandingkan senyawa alkaloid, saponin, dan terpenoid. Setiap senyawa akan memberikan nilai Rf yang berbeda pada sistem pelarut yang berbeda $^{31}$. Nilai Rf senyawa fitokimia penelitian ini sesuai dengan kisaran nilai Rf pada pelarut kloroform dan etanol penelitian lain, yaitu flavonoid (0.5 - 0.9); tanin (0.5 - 0.9); (saponin $(0.5-0.8)$; alkaloid $(0.6-0.7)$; terpenoid $(0.1$ $0.9)^{32,33}$. Senyawa dengan nilai Rf yang lebih rendah memiliki koefisien distribusi yang lebih besar, karena senyawa tertahan lebih kuat pada fase diam daripada fase geraknya ${ }^{34}$. Senyawa metabolit sekunder dengan nilai koefisien distribusi besar, secara kuantitatif cenderung memiliki jumlah yang lebih tinggi pada ekstrak daripada senyawa yang memiliki koefisien distribusi rendah dan nilai Rf besar ${ }^{35}$.
Hasil analisis fitokimia pada penelitian ini sesuai dengan studi yang dilakukan oleh Onyenekwe, et al. ${ }^{9}$ serta Soesanto \& Rahayuniati ${ }^{36}$ yang menjelaskan bahwa ekstrak tanaman pisang mengandung senyawa metabolit sekunder seperti tanin, flavonoid, terpenoid, dan alkaloid sebagai kelompok fitokimia utama.

Senyawa metabolit sekunder pada ekstrak metanol bonggol pisang ambon diduga memiliki aktivitas sebagai insektisida nabati terhadap nyamuk Aedes aegypti. Senyawa metabolit sekunder golongan alkaloid, terpenoid, tanin, saponin, dan flavonoid telah terbukti memiliki potensi untuk digunakan sebagai pengendali nyamuk Ae. aegypti?.

Ekstrak metanol bonggol pisang ambon memiliki daya toksik paling tinggi terhadap telur Ae. aegypti, dengan nilai $\mathrm{LC}_{50}$ sebesar 314,852 ppm dan mortalitas tertinggi sebesar $64 \%$ dengan lama paparan 144 jam. Efek toksisitas yang diberikan oleh ekstrak metanol bonggol pisang ambon adalah menghambat penetasan telur (Gambar. 1a)

Tabel. 2 Uji Toksisitas Ekstrak Metanol Bonggol Pisang Ambon terhadap Semua Tahap Perkembangan Nyamuk Ae. Aegypti

\begin{tabular}{|c|c|c|c|c|c|}
\hline $\begin{array}{c}\text { Tahap } \\
\text { Perkembangan } \\
\end{array}$ & $\begin{array}{c}\text { Konsentrasi } \\
(\mathrm{ppm})\end{array}$ & $\begin{array}{c}\text { Waktu } \\
\text { (Jam) }\end{array}$ & Mortality (\%) \pm SD & $\begin{array}{c}\text { LC50 } \\
\text { (ppm) }\end{array}$ & $\begin{array}{c}\text { LC90 } \\
\text { (ppm) }\end{array}$ \\
\hline \multirow[t]{8}{*}{ Telur } & 0 & 144 & $27,33 \pm 6,57 a$ & 314,852 & 6101,131 \\
\hline & 0,001 & & $41,33 \pm 5,70 \mathrm{~b}$ & & \\
\hline & 0,01 & & $54,67 \pm 4,81 \mathrm{bc}$ & & \\
\hline & 0,1 & & $50,00 \pm 5,70 \mathrm{~b}$ & & \\
\hline & 1 & & $53,33 \pm 5,70 \mathrm{bc}$ & & \\
\hline & 10 & & $53,11 \pm 3,36$ bc & & \\
\hline & 100 & & $52,22 \pm 9,05 \mathrm{bc}$ & & \\
\hline & 1000 & & $64,00 \pm 11,39 c$ & & \\
\hline \multirow[t]{8}{*}{ Larva Instar IV (L4) } & 0 & 24 & $0,00 \pm 0,00$ a & 700,086 & 1393,704 \\
\hline & 0,001 & & $0,00 \pm 0,00$ a & & \\
\hline & 0,01 & & $13,33 \pm 7,64 a b c$ & & \\
\hline & 0,1 & & $11,67 \pm 7,64 a b c$ & & \\
\hline & 1 & & $21,67 \pm 2,89 \mathrm{c}$ & & \\
\hline & 10 & & $18,33 \pm 2,89 \mathrm{bc}$ & & \\
\hline & 100 & & $6,67 \pm 2,89 a b$ & & \\
\hline & 1000 & & $71,67 \pm 17,56 \mathrm{~d}$ & & \\
\hline \multirow[t]{8}{*}{ Pupa } & 0 & 48 & $0,00 \pm 0,00 \mathrm{a}$ & 1075,296 & 2370,559 \\
\hline & 0,001 & & $15,00 \pm 8,67 \mathrm{ab}$ & & \\
\hline & 0,01 & & $15,00 \pm 8,67 \mathrm{ab}$ & & \\
\hline & 0,1 & & $23,33 \pm 11,55 b$ & & \\
\hline & 1 & & $8,33 \pm 2,89 a b$ & & \\
\hline & 10 & & $20,00 \pm 10,00 \mathrm{~b}$ & & \\
\hline & 100 & & $18,33 \pm 14,43 b$ & & \\
\hline & 1000 & & $46,67 \pm 11,55^{c}$ & & \\
\hline \multirow[t]{8}{*}{ Imago } & 0 & 48 & $0,00 \pm 0,00$ & 1755,077 & 3121,375 \\
\hline & 0,001 & & $0,00 \pm 0,00 a$ & & \\
\hline & 0,01 & & $0,00 \pm 0,00$ & & \\
\hline & 0,1 & & $0,00 \pm 0,00$ & & \\
\hline & 1 & & $13,33 \pm 5,77 b$ & & \\
\hline & 10 & & $13,33 \pm 5,77 b$ & & \\
\hline & 100 & & $10,00 \pm 0,00 b$ & & \\
\hline & 1000 & & $23,33 \pm 8,97 c$ & & \\
\hline
\end{tabular}

Keterangan : Kolom yang diikuti dengan huruf yang sama tidak berbeda secara signifikan pada taraf nyata $\mathrm{P}<0,05$. 


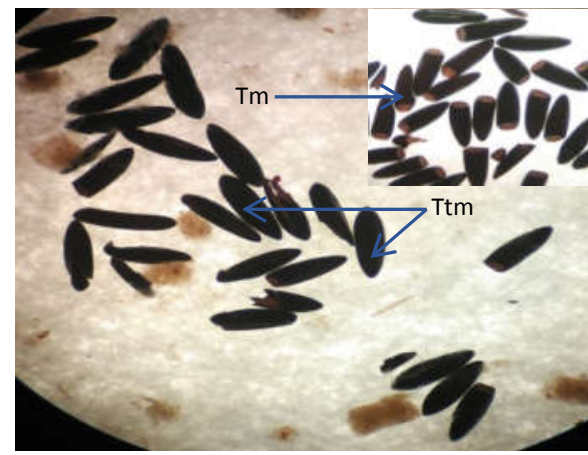

$1 \mathrm{a}$

Telur yang tidak menetas

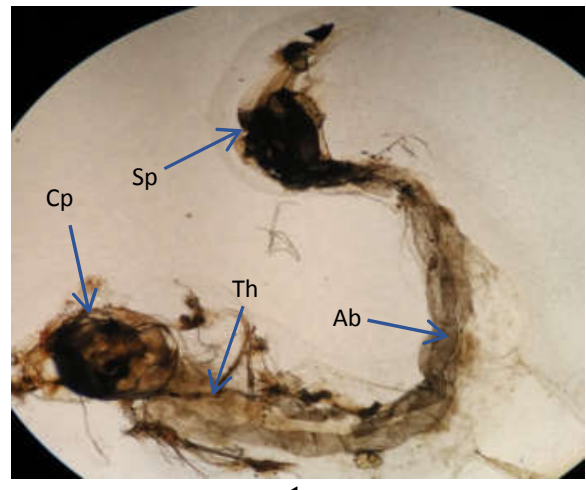

1c

Larva rusak dan lisis

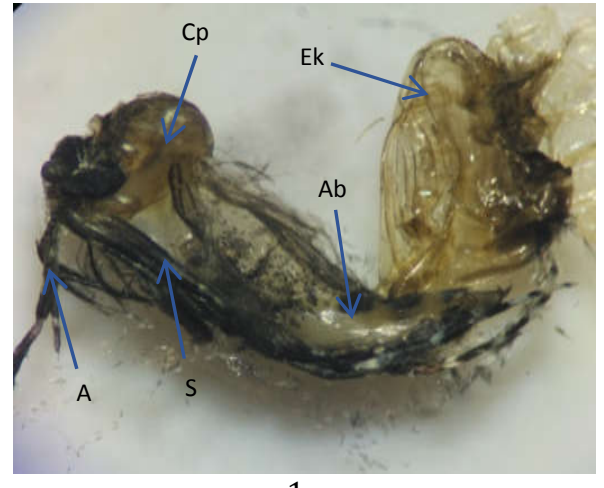

$1 \mathrm{e}$

Pupa gagal molting dan proses metamorfosis yang tidak sempurna

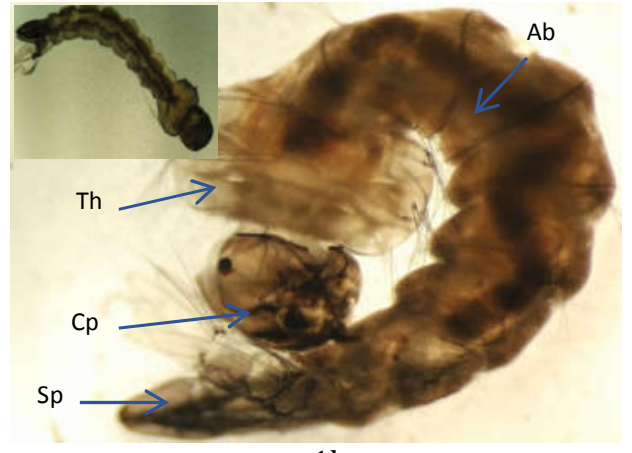

$1 \mathrm{~b}$

Larva mengalami pembengkakan

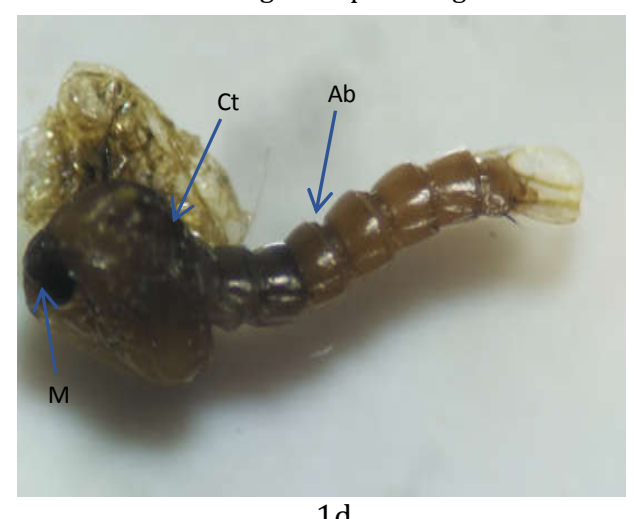

$1 \mathrm{~d}$

Pupa coklat pada sefalotorak

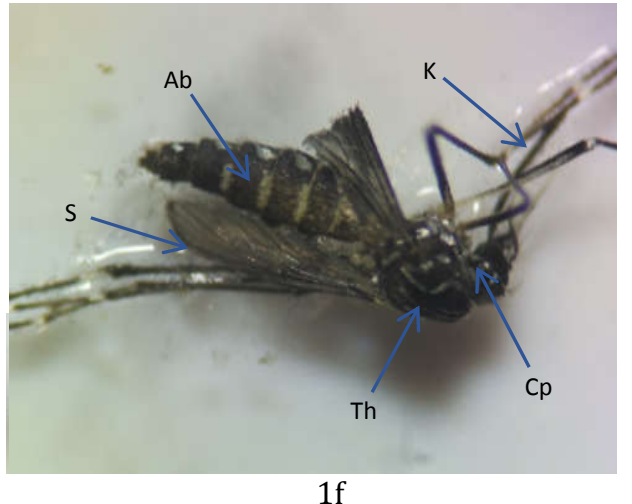

Nyamuk mengalami melanisasi (penggelapan pada abdomen)

Gambar. 1. Analisis morfologi tahap perkembangan nyamuk Ae. aegypti yang diinduksi ekstrak metanol bonggol pisang ambon konsentrasi 1000 ppm. Keterangan: Tm = telur menetas; $\mathrm{Cp}=\mathrm{sefal}$; $\mathrm{Th}$ = torak; $\mathrm{Ab}=$ abdomen; $\mathrm{Sp}=$ sifon; $\mathrm{Ct}=$ sefalotorak; $\mathrm{M}=$ mata; $\mathrm{A}$ = antena; $\mathrm{S}$ = sayap; $\mathrm{Ek}=$ eksuvia pupa; $\mathrm{K}=$ kaki.

Temuan serupa tentang aktivitas ovisida ekstrak tanaman terhadap nyamuk Ae. aegypti dicatat oleh Subashini, et al. ${ }^{37}$ menunjukkan bahwa ekstrak Scutellaria violace memberikan nilai LC50 sebesar 322,40 ppm, dan penelitian Samidurai, et al. ${ }^{38}$ melaporkan bahwa ekstrak Pemphis acidula memberikan nilai $\mathrm{LC}_{50}$ sebesar
400 ppm, dimana kedua jenis ekstrak tersebut memiliki nilai LC50 yang lebih tinggi daripada studi ini, sehingga dapat dikatakan bahwa ekstrak metanol bonggol pisang ambon memiliki efek toksik lebih tinggi untuk menghambat penetasan telur. 
Penghambatan penetasan telur diduga disebabkan oleh adanya senyawa metabolit sekunder golongan flavonoid ${ }^{39}$. Senyawa tersebut dapat masuk ke lapisan korion, sehingga mengganggu permeabilitas membran, memengaruhi proses embriogenesis, dan menyebabkan kematian embrio sehingga telur tidak dapat menetas ${ }^{28,40}$. Waktu paparan berperan penting dalam menyebabkan toksisitas, semakin lama terpapar maka semakin efektif senyawa menghambat ${ }^{41}$.

Efek toksik ekstrak metanol bonggol pisang ambon pada larva (L4) memberikan nilai LC50 sebesar 700,086 ppm setelah 24 jam paparan. Persentase mortalitas tertinggi pada konsentrasi 1000 ppm yaitu sebesar 71,67\%. Hasil studi terhadap larva L4 ini mirip dengan laporan dari Shivarman, et al. ${ }^{42}$ menyatakan bahwa ekstrak biji Semecarpus anacardium L memberikan nilai $\mathrm{LC}_{50}$ sebesar 669,96 ppm terhadap larva L4 nyamuk Ae. aegypti.

Saranya, et $a l^{43}$ dan Palanikumar, et $a .^{44}$ melaporkan bahwa senyawa golongan flavonoid yang terdapat pada ekstrak Spathodea campanulata, dan ekstrak metanol Callistemon citrinus memiliki aktivitas larvasida, yaitu dapat mengganggu fungsi mitokondria, khususnya reaksi transfer elektron sehingga menurunkan produksi ATP dan mengurangi penggunaan $\mathrm{O}_{2}$, sehingga proses metabolisme makanan terhambat. Penghambatan proses metabolisme menyebabkan terjadinya pengendapan berbagai senyawa pada usus larva, sehingga lumen perut menjadi meningkat (hipertonis) menyebabkan air dari luar usus masuk melalui proses osmosis, dan menyebabkan usus menjadi bengkak dan akhirnya lisis serta rusak, sehingga perut menjadi lumpuh dan nyamuk berhenti makan 33,45,46.

Senyawa alkaloid, saponin dan terpenoid yang terdapat pada ekstrak juga memiliki aktivitas larvasida, yang menyebabkan kerusakan midgut karena adanya degenerasi sel yang menyebabkan larva tidak berkembang dan akhirnya menyebabkan kematian ${ }^{47}$. Temuan tersebut sesuai dengan studi dari Ragavendran, et al. ${ }^{48}$, menjelaskan bahwa ekstrak Penicillium dalae menimbulkan munculnya dark black spot pada torak dan sifon. Penggelapan pada area sifon tersebut diakibatkan karena adanya senyawa metabolit sekunder yang penetrasi di kutikula saluran pernafasan, sehingga terjadi pengendapan senyawa di sifon dan menyebabkan penghambatan sistem pernafasan larva ${ }^{33,49}$.

Efek toksik ekstrak metanol bonggol pisang ambon pada pupa lebih rendah, dibandingkan telur dan larva, yaitu hanya mampu menyebabkan kematian sebesar $46,67 \%$ pupa dan memberikan nilai $\mathrm{LC}_{50}$ yang lebih besar yaitu $1075,296 \mathrm{ppm}$. Berbeda dengan studi terhadap pupa dari tanaman lain pada umumnya, diantaranya temuan Venkadachalam, et $a .^{50}$, ekstrak Tephrosia purpurea menunjukkan aktivitas pupasida yang cukup baik, dengan nilai $\mathrm{LC}_{50}$ sebesar 326,29 ppm. Jeyasankar and Chinnamani $^{51}$ melaporkan bahwa ekstrak metanol Solonum pseudocapsicum memberikan nilai LC $_{50}$ sebesar 456,39 ppm terhadap pupa nyamuk Ae. aegypti.

Beberapa penelitian sebelumnya mengungkapkan bahwa dari semua tahap perkembangan nyamuk pradewasa, pupa merupakan fase yang paling tahan terhadap insektisida nabati, yang ditunjukkan dengan nilai $\mathrm{LC}_{50}$ yang besar $^{43,44}$. Ketahanan tersebut mungkin disebabkan karena pupa merupakan tahap pradewasa yang tidak makan, sehingga mengurangi peluang mereka menelan senyawa toksik ke dalam sistem tubuh, terutama sistem pencernaan ${ }^{52,53}$. Daya toksik ekstrak pada pupa lebih rendah daripada larva, juga disebabkan karena sensitivitas Ae. aegypti menurun seiring bertambahnya usia, sehingga untuk memberikan efek toksik terhadap pupa, membutuhkan konsentrasi yang lebih tinggi dan waktu paparan yang lebih lama ${ }^{54}$.

Hasil analisis morfologi pada studi ini, sesuai dengan temuan dari Palanikumar et al.44 dan Saranya, et al. ${ }^{43}$, menunjukkan bahwa pupa yang terpapar ekstrak Spathodea campanulata dan Callistemon citrinus mengalami malformasi, yaitu pupa berperut lurus, pupa kerdil dengan perut yang mengalami retardasi, pupa coklat dan pendek, sefalotorak rusak. Kabir, et al.55 juga menemukan bahwa ekstrak Seseli diffusum menyebabkan pupa gagal molting, dimana pada bagian anterior abdomen mengalami penempelan eksuvia pupa.

Senyawa metabolit sekunder dapat menyebabkan terjadinya melanisasi yang abnormal pada kutikula pupa, sehingga menghambat proses sintesis kitin. Senyawa metabolit sekunder pada ekstrak tanaman memiliki mekanisme phototoxic yang dapat menghasilkan lesi parah pada kutikula, sehingga menjadi hitam dan gagal molting ${ }^{56}$. Kegagalan molting juga disebabkan oleh adanya gangguan pembentukan hormon juvenile (JHAs) yang berperan penting untuk molting dan metamorfosis oleh senyawa metabolit sekunder51,56. Mode aksi senyawa metabolit sekunder terhadap JHAs adalah dengan menyebabkan aktivasi proses oksidasi menghasilkan senyawa reaktif pada corpus allatum, sehingga menyebabkan kematian sel parenkim corpus allatum, dan akhirnya terjadi penurunan atau bahkan berhentinya produksi JHAs dan proses molting menjadi terhambat ${ }^{57}$.

Ekstrak bonggol pisang ambon memberikan daya toksik paling rendah pada imago 
ditunjukkan dengan nilai LC 50 yang sangat besar dibandingkan dengan nilai $\mathrm{LC}_{50}$ pada tahap perkembangan lainnya, yaitu sebesar 1755,077 ppm dalam waktu paparan selama 48 jam. Konsentrasi 1000 ppm juga hanya mampu menyebabkan kematian sebesar 23,335 \%. Hasil studi ini serupa dengan temuan dari Ajaegbu et al.58 yang mengungkapkan bahwa ekstrak metanol Spondia smombin memberikan nilai $\mathrm{LC}_{50}$ terhadap imago Ae. aegypti tertinggi pada 4061,946 ppm.

Perubahan morfologi pada imago ditemukan pada penelitian Kabir, et $a l^{55}$, yaitu adanya kelainan pada sayap imago menjadi lebih pendek. Aktivitas ekstrak terhadap malformasi morfologi pada imago belum sepenuhnya dipahami, tetapi dimungkinkan senyawa aktif bekerja dengan berbagai mode aksi, salah satunya dengan cara melumpuhkan sistem fisiologis dan osmoregulasi nyamuk ${ }^{59}$.

\section{KESIMPULAN}

Efek mortalitas tertinggi pada tahap larva, sebesar 71,67\% pada konsentrasi 1000 ppm. Daya toksik paling tinggi ditunjukkan pada tahap telur dengan nilai LC $_{50}$ 314,852 ppm, dan memberikan aktivitas berupa penghambatan terhadap penetasan telur, sedangkan paling rendah pada imago dengan nilai LC $_{50}$ 1755,077 ppm. Ekstrak metanol bonggol pisang ambon memiliki aktivitas biologi untuk merusak morfologi semua tahap perkembangan $A e$. Aegypti.

\section{UCAPAN TERIMA KASIH}

Penulis mengucapkan terima kasih kepada seluruh peneliti dan laboran serta karyawan Loka Litbang Kesehatan Pangandaran yang tidak dapat disebutkan satu persatu, yang telah membantu kelancaran proses penelitian ini.

\section{KONTRIBUSI PENULIS}

Peran penulis pada artikel ini yaitu Riyani Setiyaningsih sebagai kontributor utama. Aryani Pujiyanti, M. Choirul Hidajat, dan Lasmiati sebagai kontributor anggota. Kontribusi penulis dapat dilihat pada rincian berikut:

$\begin{array}{lll}\text { Konsep } & : & \begin{array}{l}\text { Siskha Noor K. } \\ \text { Bambang Heru B. }\end{array} \\ \text { Kurasi Data } & : & \text { Siskha Noor K. } \\ \text { Analisis Data } & : & \text { Siskha Noor K. } \\ \text { Sponsor } & : & \text { Siskha Noor K. }\end{array}$

\begin{tabular}{|c|c|c|}
\hline Pendanaan & & $\begin{array}{l}\text { Bambang Heru B. } \\
\text { Edi Basuki }\end{array}$ \\
\hline Investigasi & : & Siskha Noor K. \\
\hline Metodologi & : & Siskha Noor K. \\
\hline Sumber Daya & : & Siskha Noor K. \\
\hline Pengawasan & : & $\begin{array}{l}\text { Bambang Heru B. } \\
\text { Edi Basuki }\end{array}$ \\
\hline Validasi & : & $\begin{array}{l}\text { Siskha Noor K. } \\
\text { Bambang Heru B. } \\
\text { Edi Basuki }\end{array}$ \\
\hline Visualisasi & : & $\begin{array}{l}\text { Siskha Noor K. } \\
\text { Bambang Heru B. } \\
\text { Edi Basuki }\end{array}$ \\
\hline $\begin{array}{l}\text { Menulis-Mengkaji } \\
\text { \& Mengedit }\end{array}$ & : & $\begin{array}{l}\text { Siskha Noor K. } \\
\text { Bambang Heru B. } \\
\text { Edi Basuki }\end{array}$ \\
\hline
\end{tabular}

1. Kinansi RR, Widjajanti W, Ayuningrum FD. Haemorrhagic dengue fever's vector density status in endemic region in Indonesia (South Sumatera, Central Java, Central Sulawesi and Papua). J. Ekol Kesehat. 2017;16(1):1-9.

2. Kementerian Kesehatan Republik Indonesia. Situasi DBD di indonesia. 2016. Infodatin Pusat Data dan Informasi Kementerian Kesehatan RI: Jakarta.

3. Day, JE. Mosquito oviposition behavior and vector control. Insect. 2016;65(7):1-22. doi:10.3390/ insects7040065

4. Jung M, Kim S, Kim HG, Lethal and sublethal effects on synthetic insecticides on the locomotory and feeding behavior of Riportus pedestris (Hemiptera: Alydidae) under laboratory conditions. Journal of Asia-Pacific Entomology. 2018;21(1):179-185. doi:10.1016/j.aspen.2017. 11.019

5. Jallow MFA, Awadh DG Albaho MS, Devi VY, Ahmad N. Monitoring of pesticide residues in commonly used fruits and vegetables in Kuwait. Int J Environ Res Public Health. 2017;14(8):1-12. doi:10.3390 /ijerph14080833

6. Mukhtar MU, Mushtaq S, Arslan A, Zaki B, Hammad M, Bhatti A. Laboratory study on larvicidal activity of different plant extracts against Aedes aegypti. IJMR. 2015;2(3):127-30.

7. Showler AT. Botanically based repellent and insecticidal effects against horn flies and stable flies (Diptera: Muscidae). 2017. Journal of Integrated Pest Management 8(1): 1-11. doi: 10.1093/jipm/pmx010

8. Aboul-Enein AM, Salama ZA, Gaafar AA, Aly HF, Faten A, Ahmed HA. Identification of phenolic compounds from banana peel (Musa paradisiaca L.) as antioxidant and antimicrobial agents. J Chem Pharm Res. 2016;8(4):46-55.

9. Onyenekwe PC, Okereke OE, Owolewa SO. 
Phytochemical screening and effect of Musa paradisiaca stem extrude on rat haematological parameters. Curr Res J Biol Sci. 2013;5(1):26-9.

10. Rathy, Mc, Sajith U, Harial Cc. Plant diversity for mosquito control: A preliminary study. IJMR. 2015;29(21):29-33.

11. Onyema C, Ofor C, Okudo V, Ogbuagu A. Phytochemical and antimicrobial analysis of banana pseudo stem (Musa Acuminata). Br J Pharm Res. 2016;10(1):1-9. Available from: http://sciencedomain.org/abstract/12871

12. Deepalakshmi K, Vrameashkannan M, Mani. Mosquitocidial activity of Musa paradisiaca Linn root (banana) extracts against hazardous mosquito vector. P. Acta Biomedica Scientia. 2015;2(4):1826.

13. Wakkary JJ, Durry M, Kairupa C. Pengaruh pemberian getah bonggol pisang (Musa Paradisiaca var. sapientum L. Kuntze. AAB) terhadap penyembuhan luka bakar sayat pada kulit tikus wistar (Rattus novergicus). Jurnal e-Biomedik (eBm). 2017;5(1):1-7.

14. Kurnijasanti R, Putri AA. The effects of banana stem (Musa paradisiaca var. sapientum) extract on histopatologic gastric of rats induced by indometachin. Folia Medica Indonesiana. 2017;5(4): 246-250.

15 Jyothirmayi N, Rao NM. Banana medicinal uses. J Med. Sci. Tech. 2015;4(2):152-160.

16. Ningsih AP, Nurmiati, Agustien, A. Uji aktivitas antibakteri ekstrak kental tanaman pisang kepok kuning (Musa paradisiaca Linn.) terhadap Staphylococcus aureus dan Escherichia coli. Jurnal Biologi Universitas Andalas. 2013;2(3): 2107-213.

17. Obiageli O, Izundu AI, Helen ON, Pauline IA. Phytochemical compositions of fruits of three musa species at three stages of development. IOSR-JPBS 2016;11(3):48-59. DOI: $\quad 10.9790 / 3008$ 1103044859.

18. Hapsari L, Lestari DA. Fruit Characteristic and Nutrient values of four indonesian banana cultivars (Musa spp) at different genomic groups. AGRIVITA. 2016;38(3):303-311. doi.org/10.17503/agrivita.v38i3.696

19. Asuquo EG, Udobi CE. Antibacterial and toxicity studies of the ethanol extract of Musa paradisiaca leaf. Cogent Biology, [Online]. 2016; 2(1), Pp.1-10. Available At: Https://www.cogentoa.com/Article /10.1080/23312025.2016.1219248.

20. Rao USM, Abdurrazak M, Mohd KS. Penyaringan fitokimia, jumlah asai kandungan flavonoid dan fenolik pelbagai ekstrak pelarut tepal Musa paradisiaca. Malaysian J Anal Sci. 2016;20(5):1181-90.

21. Ramdan AM, Kiki MY, Esti SR. Identifikasi senyawa yang memiliki aktivitas antibakteri pada getah pelepah pisang manggala (Musa paradisiaca L.) dengan metode bioautografi kontak. Prosiding Penelitian Spesia Unisba (Kesehatan dan Farmasi). 2015; 637-642.

22. Sharma, V. And Pracheta, J. Extraxtion, Isolation and identification of flavonoid from Euphorbia neriifolia leaves. Arabian Journal Of Chemistry. 2017; 10;509-514. http://dx.doi.org/10.1016 /j.arabjc.2014.08.019.

23. Hassan, IA, Idris, AN., Amina, MM, Ibrahim, AS,
Audu, SA. Phytochemical studies and thin layer chromatography of leaves and flower extracts of Senna siamea Iam for possible medical applications. Academic Journal. 2015;7(3);1826.Https://Doi.Org/10.5897/JPP2014.0337.

24. Rikomah, SE, Elmitra. Identifikasi senyawa saponin ekstrak etanol pelepah pisang uli (Musa paradisiaca L.). Scientia. 2017;7 (1): 56-60.

25. Hamid HK, Enas JK. Extraction, isolation and characterization of pyrrolizidine alkaloids present in Senecio vulgaris Linn grown in Iraq. J Pharmacogn Phytochem. 2016;5(6), Pp.28-37.

26. Biradar SR, Bhagyashri DR. Extraction of some secondary metabolites \& thin layer chromatography from different parts of Centella asiatica L. (URB). AJLS. 2013;1(6), Pp.243-247. Doi: 10.11648/J.Ajls.20130106.11.

27. Munusamy, RG, Appadurai DR, Kuppusamy S, Michael GP, Savarimuthu I. Ovicidal and larvacidal activities of some plant extract against Aedes aegypti L and Culex quinquefasciatus (Say.) (Diptera: Culicidae). Asian Pac J Trop Dis. 2016;6(6):468-471. doi.org/10.1016/S22221808(16)61070-8

28. Sarma R, Khanikor B, Mahanta S. Essential oil from Citrus grandis (Sapindales: Rutaceae) as insecticide against Aedes aegypti (L) (Diptera: Culicidae). Int J Mosq Res. 2017;4(3):88-92.

29. Krzyzaniak LM, Ushirobira TMA, Panizzon G,Sereia $\mathrm{AL}$, de Souza JRP, Zequi JAC, Novello CR, et al. Larvacidal activity against Aedes aegypti and chemical characterization of the inflorescences of Tagates patula. Evidence-Based Complementary and Alternative Medicine. 2017;1-9. doi.org/10.1155/2017/9602368

30. Selvakumar B, Gokulakrishnan J, Elanchezhiyan K, Deepa J. Mosquito Larvicidal , Ovicidal and pupicidal activities of Annona reticulata Linn (Annonaceae) against Aedes aegypti (Linn.), Anopheles stephensi Liston and Culex quinquefasciatus (Say) (Diptera : Culicidae). IJRSR. 2015;6:2690-6.

31. Sharma M, Abid R, Sajgotra, M. Phytochemical screening and thin layer chromatography of Ficus carica leaves extract. UKJPB. 2017; 5(1): 18-23.

32. Ogbuanu CC, Echiri RC, Ogah SPI. Phytochemical screening and preliminary TLC characterization of alkaloids in Sabicea brevies Root. Research Journal of Phytochemistry. 2014; 8(1): 1-8.

33 Yahyoui OEI, et al. Phytochemical screening and thin layer chromatography of two medicinal plants: Adansonia digitata (Bombacaceae) and Acacia raddiana (Fabaceae). J Pharmacogn Phytochem. 2017; 6(1): 10-15

34. Rahmawati, F. Optimasi penggunaan kromatografi lapis tipis (KLT) pada pemisahan senyawa alkaloid daun pulai (Alstonia scholaris L.R.Br). 2015. UIN Malang.

35. Ahamed T, Rahman SKM, Shohael AM. Thin layer chromatography profiling and phytochemical screening of six medicinal plants in Bangladesh. IJB. 2017.11(1): 131-140. DOI: 10.12692/ijb/11.1.131$140\}$

36. Ehiowemwenguan G, Emoghene AO, Inetianbor JE. Antibacterial and phytochemical analysis of banana fruit peel. Journal of Pharmacy. 2014;4(8):18-25. 
37. Subashini, K, Sivakami, S And Jeyasankar, A. Phytochemical screening and ovicidal activity of Scutellaria violacea (Lamiaceae) leaf extract against vector mosquitoes (Diptera: Culicidae). Int J Adv Res Biol Sci. 2017;4(3):152-8.

38. Reegan D, Paulraj MG, Kinsalin AV, Ignacimuthu S. Larvicidal, ovicidal and repellent activities of marine sponge Cliona celata (Grant) extract against Anopheles stephensi Liston (Diptera: Culcidae). Asian Pac J Trop Biomed. 2015;8(1):29-34. DOI: 10.1016/S1995-7645(14)60183-8

39. Dhivya TN, Nadu T. Phytochemical composition and ovicidal efficacy of Catharanthus roseus leaf extract against the mosquito Culex quinquefasciatus (Diptera: Culicidae). JEZS. 2017;5(3): 44-9.

40. Dishani UA, Dhivya R. Preliminary phytochemical profiling and ovicidal potential of Carica papaya leaf extracts against the filarial vector Culex quinquefasciatus (Diptera: Culicidae). Int. J. Mosq. Res. 2017;4(3): 1-8.

41. Dhal P,Rout JR, Dash PK, Panda S, Pati P, Rath CC, et al. Larvacidal and pupicidal activity of Clerodendrum philippinum Schauer leaf extracts against Anopheles stephensi and Aedes aegypti. Pharmacogn J. 2018;10(6):1137-1142. doi $: 10.5530 /$ pj.2018.6.194

42. Sivaraman G, Reegan AD, Paulraj MG, Ignacimuthu S. Toxicity of Semecarpus anacardium L. seed extracts against immature stages of Culex quinquefasciatus Say and Aedes aegypti L. (Diptera: Culcidae) . JEZS. 2018;6(2):2068-2017.

43. Saranya M, Mohanraj RS, Dhanakkodi B. Larvicidal, pupicidal activities and morphological deformities of Spathodea campanulata aqueous leaf extract against the dengue vector Aedes aegypti. Euro. J. Exp. Bio. 2013;3(2):205-13.

44. Palanikumar M, Pravin $Y$, Navaneethan $M$, Mahendren S, Rs M. Callistemon Citrinus Myrtaceae) Methanolic leaf extract: A potent mosquitocidal agent for controlling dengue vector mosquito Aedes aegypti (Diptera : Culicidae). JEZS. 2017;5(3):1051-9.

45. Mendes LA, Martins GF, Valbon WR, Da Silva De Souza T, Menini L, Ferreira A, et al. Larvicidal effect of essential oils from brazilian cultivars of guava on Aedes aegypti L. Ind Crops Prod [Internet]. 2017;108(May):684-9. Available From: http://dx.doi.org/10.1016/j.indcrop.2017.07.034

46. Gama ZP, Nakagoshi N, Suharjono, Setyowati F. Toxicity studies for indigenous Bacillus thuringiensis isolates from Malang City, East Java On Aedes aegypti larvae. Asian Pac J Trop Biomed [Internet]. 2013;3(2):111-7. Available From: Http://Dx.Doi.Org/10.1016/S22211691(13)60034-9

47. Arivoli S, Raveen R, Tennyson S, Sakthivadivel M. Adult emergence inhibition activity of Cleistanthus collinus (Roxb.) (Euphorbiaceae) leaf extracts against Aedes aegypti (L.), Anopheles stephensi Liston, and Culex quinquefasciatus Say (Diptera: Culicidae). IJMR. 2015;2(1):24-8.

48. Ragavendran C, Mariappan T, Natarajan D. Larvicidal, histopathological efficacy of Penicillium daleae against larvae of Culex quinquefasciatus and Aedes aegypti plus biotoxicity on Artemia nauplii a non-target aquatic organism. Front Pharmacol. 2017;8:1-14.

49. Dias CN, Moraes DFC. Essential oils and their compounds as Aedes aegypti L. (Diptera: Culicidae) larvicides. Parasitol Res. 2014;113 (2):565-92.

50. Venkadachalam R, Subramaniyan V, Palani M, Subramaniyan M, Srinivasan P, Raji M. Mosquito larvicidal and pupicidal activity of Tephrosia purpurea Linn. (Family: Fabaceae) and Bacillus sphaericus against dengue vector Aedes aegypti. Pharmacogn J. 2014;9(6):737-42.

51. Jeyasankar A, Chinnamani T. Larvacidal and pupicidal activities of Solonum pseudocapsicum fruits compunds against Aedes aegypti, Anopheles stephensi and Culex quinquefasciatus (Diptera: Culcidae). J Infectious Disease Med Microbiol. 2018;2(2):S11-16.

52. Soonwera M, Phasomkusolsil S. Adulticidal, Larvicidal, Pupicidal and oviposition deterrent activities of essential oil from Zanthoxylum limonella Alston (Rutaceae) against Aedes aegypti (L.) and Culex quinquefasciatus (Say). Asian Pac J Trop Biomed. 2017;7(11):967-78. Available from: https://doi.org/10.1016/j.apjtb.2017.09.019

53. Ileke KD, Oyeniyi EA, Charles O, Adesina JM. Nicotiana tabacum a prospective mosquitocide in the management of Anopheles gambiae (Giles). IJMR. 2015;2(4):19-23.

54. Pratheeba T, Ragavendran C, Natarajan D. Larvacidal, pupicidal and adulticidal potential of Ocimum gratissimum plant leaf extracts against filariasis inducing vector. IJMR. 2015;2(2):1-8.

55. Kabir KE, Choudhary MI, Ahmed S, Tariq RM. Growth-disrupting, larvicidal and neurobehavioral toxicity effects of seed extract of Seseli diffusum against Aedes aegypti (L.) (Diptera: Culicidae). Ecotoxicol Environ Saf. 2013;90:52-60. Available from: http://dx.doi.org/10.1016/j.ecoenv.2012. 12.028

56. Ga'al H, Fouad H, Mao G, Tian J, Jianchu M. Larvicidal and pupicidal evaluation of silver nanoparticles synthesized using Aquilaria sinensis and Pogostemon cablin essential oils against dengue and zika viruses vector Aedes albopictus mosquito and its histopathological analysis. Artif Cells, Nanomedicine Biotechnol. 2017;0(0):1-9. Available from: https://doi.org/10.1080/ 21691401.2017.1365723

57. Lee SH, Oh HW, Fang Y, An SB, Park DS, Song HH, et al. Identification of plant compounds that disrupt the insect juvenile hormone receptor complex. PNAS. 2015; 112(6): 1733-1738.

58. Ajaegbu EE, Danga SPY, Chijoke IU, Okoye FBC. Mosquito adulticidal activity of the leaf extract of Spondias mombin L. against Aedes aegypti L and isolation of active principles. J Vector Borne Dis. 2016;53(1):17-22.

59. Cutler GC. Insects, insecticides and hormesis: Evidence and considerations for study. Dose Response. 2013;11(2):154-177. doi: 10.2203/ dose-response.12-008.Cutler. 